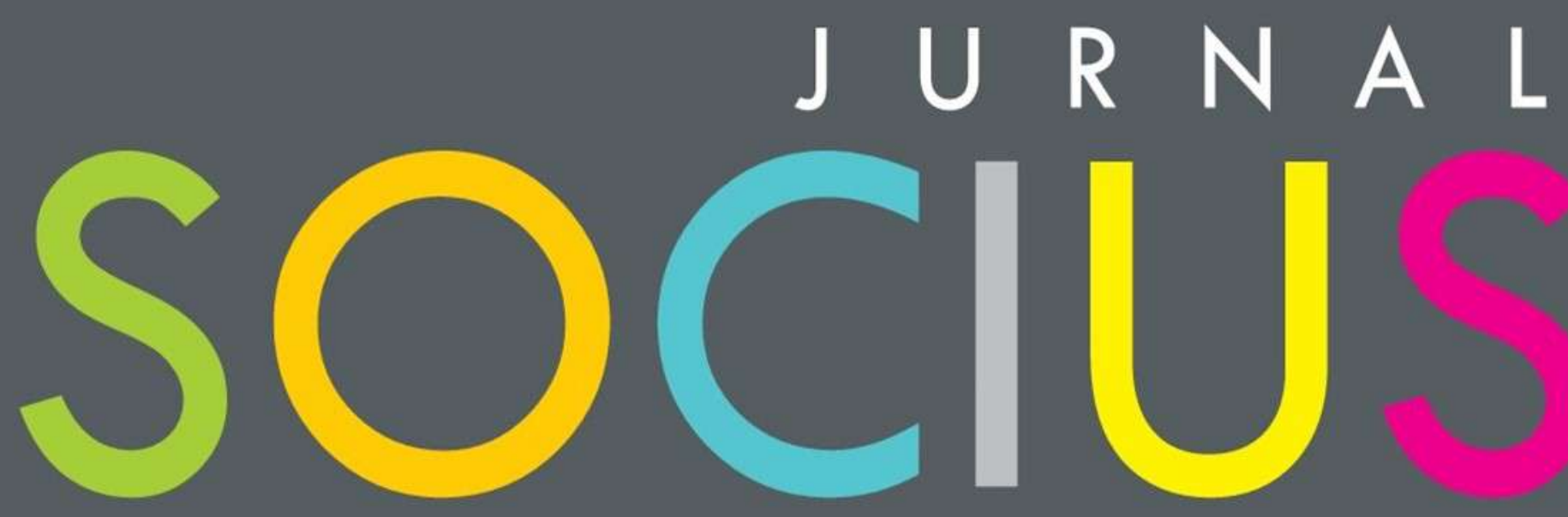

Journal of Sociology Research and Education

DITERBITKAN OLEH :

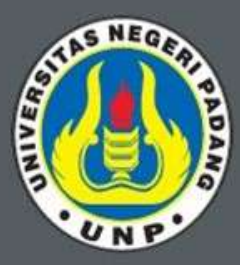

LABOR JURUSAN SOSIOLOGI FAKULTAS ILMU SOSIAL UNIVERSITAS NEGERI PADANG

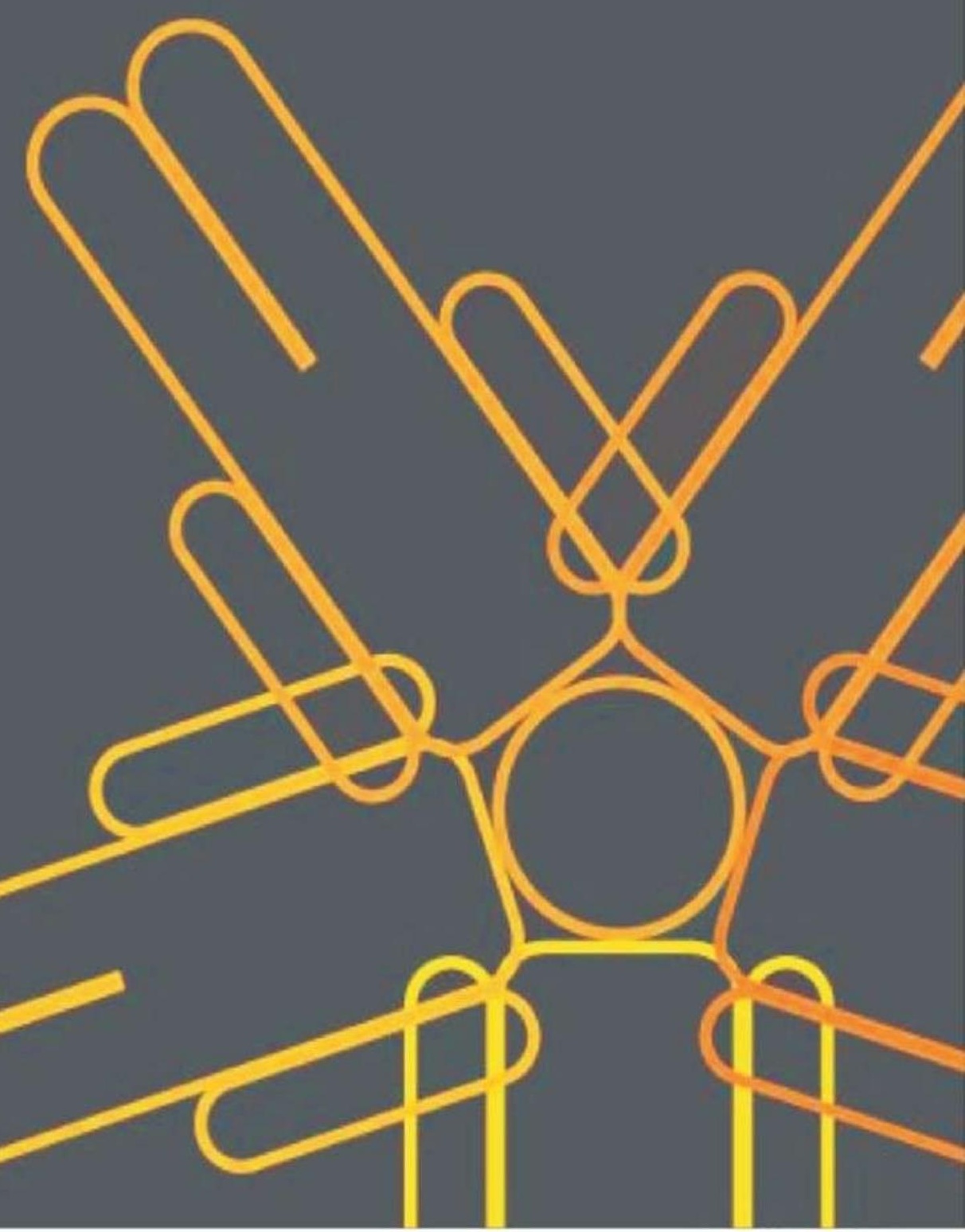




\section{SOCIUS}

Vol. 6, No.2, Th. 2019

ISSN : 2356-4180 (cetak)

2442-8663 (online)

\begin{tabular}{|c|c|}
\hline $\begin{array}{c}\text { REDAKSI } \\
\text { JURNAL SOCIUS }\end{array}$ & DAFTAR ISI \\
\hline $\begin{array}{c}\text { Editor in Chief : } \\
\text { Selinaswati } \\
\text { Managing Editor : } \\
\text { Erda Fitriani } \\
\text { Editorial Board: } \\
\text { Eka Vidya Putra } \\
\text { Desy Mardiah } \\
\text { Ike Sylvia } \\
\text { Erianjoni } \\
\text { Mohammad Isa Gautama } \\
\text { Reno Fernandes }\end{array}$ & $\begin{array}{c}\text { Mutia Kahana, Junaidi } \\
\text { Pengaruh Penerapan Model Konsiderasi Terhadap Pembentukan } \\
\text { Sikap Siswa dalam Pembelajaran Sosiologi di Kelas XI IPS SMA } \\
\text { Adabiah Padang } \\
\text { Halaman 62-69 } \\
\text { Reno Fernandes } \\
\text { Revolusi 4.0 } \\
\text { Halaman } 70-80\end{array}$ \\
\hline $\begin{array}{c}\text { Reviewer: } \\
\text { Rebecca Fanany } \\
\text { Elly Malihah } \\
\text { (Deakin Univerity, Australia) } \\
\text { (Universitas Pendidikan Indonesia, Indonesia) } \\
\text { Nur Hidayat Sardini } \\
\text { (Universitas Diponegoro, Indonesia) } \\
\text { Ubedilah Badrun } \\
\text { ( Universitas Negeri Jakarta, Indonesia) } \\
\text { Moh. Yasir Alimi } \\
\text { (Universitas Negeri Semarang, Indonesia) } \\
\text { Ferdinand Kerebungu } \\
\text { (Universitas Negeri Menado, Indonesia) } \\
\text { Jendrius } \\
\text { (Universitas Andalas, Indonesia) } \\
\text { Lucky Zamzami } \\
\text { (Universitas Andalas, Indonesia) } \\
\text { Adri Febrianto } \\
\text { (Universitas Negeri Padang, Indonesia) } \\
\text { Ikhwan } \\
\text { Aisiah } \\
\text { (Universitas Negeri Padang, Indonesia) } \\
\text { (Universitas Negeri Padang, Indonesia) } \\
\text { Junaidi Indrawadi } \\
\text { (Universitas Negeri Padang, Indonesia) } \\
\text { Sadri Chaniago } \\
\text { (Universitas Andalas, Indonesia) }\end{array}$ & $\begin{array}{c}\text { Andreas Dego, Yoseph D.A. Santie, Sem Deehop, Ferdinand } \\
\text { Kerebungu } \\
\text { Analisis Kompetensi Pedagogik Guru IPS di SMP Negeri } 1 \text { Kabupaten } \\
\text { Pulau Morotai } \\
\text { Halaman } 81-89 \\
\text { Yuyut Chandra, Aidinil Zetra, Ria Ariyany } \\
\text { LKAAM Kota Solok) } \\
\text { Halaman 90-102 } \\
\text { Demokrasi Deliberatif Masyarakat Minangkabau (Studi Kasus: } \\
\text { Ike Sylvia, Syafri Anwar, Khairani } \\
\text { Pengembangan Instrumen Penilaian Autentik Berbasis Pendekatan } \\
\text { Authentic Inquiry Learning Pada Mata Pelajaran Sosiologi di Sekolah } \\
\text { Menengah Atas } \\
\text { Halaman 103-120 } \\
\text { Pawennari Hijjang, Lia Amelia } \\
\text { Assajingeng: Politik Kekerabatan di Pilkada Kabupaten Bone (Analisis } \\
\text { Antropologi Politik) } \\
\text { Halaman 121-134 }\end{array}$ \\
\hline $\begin{array}{c}\text { Layout Editor : } \\
\text { Rhavy Ferdyan, S.Pd. } \\
\text { Technical Support: } \\
\text { Rudi Mahesa, A.Md. } \\
\text { Alamat Redaksi: } \\
\text { Jurusan Sosiologi FIS UNP } \\
\text { Jl. Prof.Dr.Hamka } \\
\text { Kampus UNP Air Tawar } \\
\text { e-mail: sosan@ fis.unp.ac.id } \\
\text { Penerbit } \\
\text { Labor Jurusan Sosiologi } \\
\text { Universitas Negeri Padang }\end{array}$ & \\
\hline
\end{tabular}




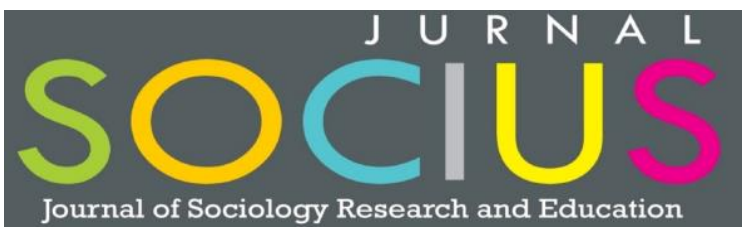

Jurnal Socins: Journal of Sociology Research and Education Vol.6, No.2, Th. 2019

ISSN: Online 2442-8663 - Print 2356-4180

http://socius.ppj.unp.ac.id/index.php/socius

Email: socius@ppj.unp.ac.id

DOI: https://doi.org/10.24036/scs.v6i2.162

\title{
Pengembangan Instrumen Penilaian Autentik Berbasis Pendekatan Authentic Inquiry Learning pada Mata Pelajaran Sosiologi di Sekolah Menengah Atas
}

\author{
Ike Sylvia $^{1}$, Syafri Anwar ${ }^{2}$, Khairani Khairani ${ }^{3}$ \\ 1,2,3 Universitas Negeri Padang \\ Email: ikesylvia@fis.unp.ac.id, syafrianwar@fis.unp.ac.id, khairani@fis.unp.ac.id
}

\begin{abstract}
Abstrak
Artikel ini bertujuan untuk mendesripsikan (1) karakteristik instrumen penilaian autentik berbasis authentic inquiry learning pada pembelajaran sosiologi yang cocok untuk peserta didik SMA, (2) kelayakan instrumen penilaian autentik berbasis authentic inquiry learning, (3) pencapaian kompetensi sosiologi, kemampuan $4 \mathrm{C}$ dan HOTS peserta didik yang diukur menggunakan instrumen penilaian autentik berbasis authentic inquiry learning. Jenis ini adalah penelitian $\mathrm{R} \& \mathrm{D}$, prosedur pengembangan menggunakan model ADDIE. Hasil penelitian menunjukkan bahwa (1) karakteristik instrumen penilaian autentik berbasis authentic inquiry learning pada pembelajaran sosiologi yang cocok untuk peserta didik SMA terdiri dari instrumen penilaian kognitif, penilaian sikap, penilaian keterampilan. (2) Instrumen penilaian autentik berbasis authentic inquiry learning memiliki validitas 0,829 (tinggi) dan reliabilitas 0,697 (tinggi) sehingga layak dan dapat diimplementasikan, (3) Ketercapaian kompetensi sosiologi peserta didik pada aspek pengetahuan rerata 3,0 (B), aspek sikap rerata 3,5 (B+), dan aspek keterampilan rerata 3,1 (B). (4) Proses penilaian kompetensi menggunakan instrumen penilaian autentik berbasis authentic inquiry learning dapat mengembangkan kecakapan peserta didik dalam komunikasi, kolaboratif, berfikir kritis dan pemecahan masalah, serta kreativitas dan inovasi, (5) Domain kognitif, afektif dan psikomotor peserta didik dapat berkembang lebih maksimal jika proses pembelajaran dan penilaian dirancang, dilaksanakan dan dievaluasi secara holistik dan berkesinambungan.
\end{abstract}

Kata kunci: Authentic Inquiry Learning, HOTS, Kecakapan Abad 21, Penilaian Autentik, Pembelajaran Sosiologi

\begin{abstract}
This article intended to describe (1) the characteristics of authentic assessment instruments based on authentic inquiry learning in sociology learning that is suitable for high school students. 2) the feasibility of authentic assessment instruments based on authentic inquiry learning, (3) enhancing sociological competence, the ability of $4 C$, and HOTS participating students use the instrument. This type is $R \& D$ research, development procedures using ADDIE models. The results showed that (1) the characteristics of authentic assessment instruments based on authentic learning inquiry on sociology learning suitable for high school students. consisted of cognitive assessment instruments, attitude evaluation, Increase ability. (2) Authentic assessment instruments based on authentic learning have validity 0.829 (high) and reliability 0.697 (high) are feasible and can be implemented, (3) Achievement of sociological competencies of students by average resources $3.0(B)$, average resources $3,5(B+)$, and average skill aspect 3.1 (B). (4) Competency Assessment Process using authentic assessment instruments based on authentic inquiry learning can develop students' skills in communication, collaborative, critical thinking and problem solving, creativity and innovation, (5) The cognitive, affective and psychomotor domains of students will develop more optimally if the learning and thought process designed, implemented and evaluated holistically and continuously.
\end{abstract}

Key words : Authentic Assessment, Authentic Inquiry Learning, HOTS, Sociology Learning, 21st Century Skills

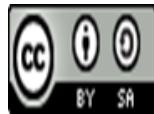

Received: December 6, 2019

Revised: December 30, 2019

Available Online: December 31, 2019

Jurnal Socius: Journal of Sociology Research and Education Vol. 6, No.2, Th. 2019

ISSN: Online 2442-8663 - Print 2356-4180 


\section{Pendahuluan}

Perkembangan ilmu pengetahuan dan teknologi telah mengubah wajah peradaban dunia. Revolusi industri generasi ke empat (4.0) memiliki ciri khas berkembangnya teknologi yang semakin mutakhir, selain itu juga memiliki tantangan dan permasalahan. Salah satu tantangan yang harus dihadapi adalah perbaikan sektor Sumber Daya Manusia (SDM) yang dapat diantisipasi melalui peningkatan kualitas pendidikan. Hal yang paling fundamental adalah mengubah pola pikir dan sifat peserta didik dalam mengembangkan kemampuannya dalam menghadapi revolusi industri 4.0 sehingga dapat menjadi sumber daya manusia yang unggul. Untuk itu, ada kecakapan yang harus dimiliki oleh setiap individu agar tetap bersaing dan diperhitungkan dalam kehidupan pada abad ke-2, yaitu, (1) critical thinking and problem solving, (2) collaboration, (3) good communication, (4) creative and innovative thinking skill, (5) social responsibility, (6) work ethic.

Kurikulum nasional yang digunakan dalam pembelajaran saat ini dikenal dengan nama kurikulum 2013, telah memberikan arahan jelas bahwa peserta didik wajib memiliki pengalaman belajar dengan memberikan penekanan perlunya penyelidikan ilmiah (inquiry) agar peserta didik mampu melakukan sinkronisasi antara materi yang dipelajari dan realita yang ada disekitarnya (authentic), dengan harapan peserta didik mampu mengkonstruksi konsep serta melatih kemampuan metakognitifnya.

Kemampuan interpretasi dan penerapan kebijakan kurikulum di sekolah oleh lembaga, pimpinan, sekolah serta guru mata pelajaran adalah faktor penentu terbentuknya kompetensi peserta didik yang sesuai dengan harapan. Pembelajaran dan penilaian yang dilaksanakan secara terintegrasi dapat mengembangkan kemampuan afektif, kognitif dan psikomotor peserta didik, agar menghasilkan insan terdidik yang memiliki pribadi berkarakter, berprestasi, dan memiliki keterampilan yang dibutuhkan di abad ke-21.

Tantangan berikutnya adalah guru abad 21 perlu mempersiapkan peserta didik yang unggul dan memiliki kecakapan tersebut. Tugas guru adalah mendesain, melaksanakan pembelajaran sesuai dengan rancangannya, serta mampu mengevaluasinya. Selain itu guru juga perlu memikirkan cara mentransformasikan kecakapan tersebut ke dalam diri para peserta didiknya melalui perencanaan, pelaksanaan, dan evaluasi pembelajarannya secara terarah, efektif dan efisien. Dengan dibekali kecakapan ini sebagai tambahan kecakapan akademik peserta didik akan terbantu memecahkan permasalahan individual dan sosial yang dihadapi dalam kehidupan di lingkungannya.

Untuk menghadapi tantangan tersebut, Menteri Pendidikan dan Kebudayaan dalam Permendikbud No 22 Tahun 2016 telah mencanangkan 14 prinsip pembelajaran yang sesuai dengan Standar Kompetensi Lulusan dan Standar Isi, yaitu (1) perubahan paradigma pada proses pembelajaran dari peserta didik diberi tahu peserta didik mencari tahu, (2) pembelajaran menggunakan berbagai sumber belajar, tidak lagi mengandalkan guru sebagai satu-satunya sumber belajar, (3) pembelajaran tidak lagi tekstual namun mengarahkan pada penguatan penggunaan pendekatan ilmiah, (4) perubahan dari pembelajaran berbasis konten menuju pembelajaran berbasis kompetensi, (5) pembelajaran tidak lagi parsial namun menuju pembelajaran terpadu, (6) Pembelajaran tidak lagi menekankan jawaban tunggal namun jawaban yang multi dimensi, (7) dari pembelajaran verbalisme menuju keterampilan aplikatif, (8) perlunya peningkatan dan keseimbangan antara keterampilan fisikal (hardskills) dan keterampilan mental (softskills); (9) mengutamakan pembudayaan dan pemberdayaan peserta didik sebagai pembelajar sepanjang hayat, (10) menerapkan nilai-nilai dengan memberi keteladanan, membangun kemauan, dan mengembangkan kreativitas peserta didik dalam proses pembelajaran; (11) pembelajaran yang berlangsung di rumah, di sekolah, dan di 
masyarakat, (12) pembelajaran yang menerapkan prinsip bahwa siapa saja adalah guru, siapa saja adalah peserta didik, dan di mana saja adalah kelas, (13) pemanfaatan teknologi informasi dan komunikasi untuk meningkatkan efisiensi dan efektivitas pembelajaran, (14) pengakuan atas perbedaan individual dan latar belakang budaya peserta didik. Sesuai dengan prinsip diatas maka dikembangkanlah standar proses yang mencakup perencanaan proses pembelajaran, pelaksanaan proses pembelajaran, penilaian hasil pembelajaran, dan pengawasan proses pembelajaran, dimana sasaran pembelajaran mencakup pengembangan ranah sikap, pengetahuan, dan keterampilan yang dielaborasi untuk setiap satuan pendidikan. (Permendikbud No 22, 2016)

Kompetensi inti pada kurikulum 2013 merupakan tingkat kemampuan untuk mencapai standar kompetensi lulusan yang harus dimiliki seorang peserta didik pada setiap tingkat kelas, yang terdiri atas kompetensi inti sikap spiritual, sikap sosial, pengetahuan, dan keterampilan. Sedangkan kompetensi dasar merupakan kemampuan dan materi pembelajaran minimal yang harus dicapai peserta didik untuk suatu mata pelajaran pada masing-masing satuan pendidikan yang mengacu pada kompetensi inti. (Permendikbud No 22, 2016)

Pembelajaran sosiologi memiliki dimensi konseptual dan sekaligus praktis serta memperkuat komitmen nilai. Tujuan pembelajaran sosiologi adalah untuk menumbuhkan kualitas berpikir yang mampu mendorong keterlibatan peserta didik dalam dunia publik. Dengan kata lain, pembelajaran sosiologi mementingkan penguasaan pengetahuan, nilai kemanusiaan dan keterlibatan sosial. (Silabus Sosiologi Kurikulum 2013 Revisi, 2016).

Pembelajaran sosiologi di kelas X diharapkan peserta didik mampu menumbuhkan kesadaran individual dan sosial. Selanjutnya, di kelas XI diharapkan peserta didik dapat memiliki kepekaan dan kepedulian terhadap masalah-masalah sosial serta tanggungjawab pemecahan masalah sosial. Pada kelas XII, peserta didik diharapkan memiliki keberdayaan diri dan kemampuan untuk melakukan pemberdayaan komunitas. Setelah lulus dari SMA diharapkan peserta didik menjadi warga negara yang memiliki kesadaran sosial, kepekaan dan kepedulian terhadap kelestarian lingkungan hidup dan masalah-masalah sosial serta mampu mengatasi masalah dan melakukan pemberdayaan sosial di masyarakat. Berdasarkan kompetensi yang hendak dicapai itu, praktik pembelajaran sosiologi ditujukan pada penguasaan pengetahuan dalam praktik, atau praktik pengetahuan sosiologi, untuk mengembangkan keterampilan sosial dan menumbuhkan sikap religiusitas dan etika sosial yang tinggi dalam pergaulan sosial di masyarakat. Proses pembelajaran sosiologi dijalankan dengan menekankan pentingnya penguasaan pengetahuan sosiologi yang berorientasi pada praktik untuk mengembangkan keterampilan sosial dan menumbuhkan sikap religius dan etika sosial sebagai wujud tanggung jawab peserta didik sebagai manusia dewasa dan warga negara terhadap masalah-masalah sosial di masyarakat. Secara keseluruhan, hal itu dimaksudkan untuk menumbuhkan kesadaran individual atau diri dan sosial peserta didik di tengah keragaman sosial atau pluralitas yang ada, menghormati perbedaan dan bersikap toleran terhadap perbedaan di tengah pluralitas masyarakat Indonesia. (Silabus Sosiologi Kurikulum 2013 Revisi, 2016).

Pelaksanaan proses pembelajaran dan melakukan penilaian proses serta hasil belajar adalah sebuah aktivitas yang tidak dapat dipisahkan, yang bertujuan agar dapat memantau kualitas pembelajaran dan memberikan feedback untuk perbaikan, sehingga perancangan strategi penilaian oleh pendidik sudah harus dibuat saat penyusunan rencana pelaksanaan pembelajaran (RPP) yang mengacu pada silabus. Sesuai dengan Permendikbud No 23 mengenai Standar Penilaian Pendidikan, ditetapkan bahwa penilaian aspek sikap dilakukan melalui observasi/pengamatan dan teknik penilaian lain yang relevan; penilaian aspek pengetahuan dilakukan melalui tes tertulis, tes lisan, dan penugasan sesuai dengan kompetensi 
yang dinilai; sedangkan penilaian keterampilan dilakukan melalui praktik, produk, proyek, portofolio, dan/atau teknik lain sesuai dengan kompetensi yang dinilai. (Permendikbud No 23, 2016)

Kualitas pelaksanaan pembelajaran di sekolah adalah pondasi awal keberhasilan proses pendidikan, namun saat ini penilaian sumatif sering menjadi acuan orang tua dan guru dalam melihat kompetensi yang telah diperoleh peserta didik. Nilai ulangan ataupun nilai rapor menjadi hal yang paling umum dalam melihat prestasi peserta didik. Akan tetapi, justru kebermaknaan dari pembelajaran yang dilalui oleh peserta didik yang akan mengantarkan peserta didik belajar menuju kesuksesan masih sering diabaikan. (Ferita, 2017). Semestinya asesmen dan evaluasi pendidikan berfungsi sebagai penyedia informasi dan pengendali mutu pendidikan, mencakup semua komponen pendidikan, proses pelaksanaan dan produk pendidikan secara menyeluruh, artinya asesmen merupakan suatu bagian yang terintegrasi dengan perencanaan dan proses pelaksanaan pembelajaran. (A. Muri Yusuf, 2017).

Berdasarkan data hasil penelitian pendahuluan yang dilakukan pada guru sosiologi yang tergabung dalam MGMP Sosiologi SMA provinsi Sumatera Barat dan MGMP Sosiologi SMA Kota Padang (2018), guru mengungkapkan bahwa mereka telah berusaha membuat rencana pembelajaran sesuai dengan arahan Permendikbud No 22 tahun 2016, yaitu membuat rancangan pembelajaran dengan mengelaborasi berbagai model pembelajaran, mengintegrasikan domain kognitif, afektif dan psikomotor, kecakapan 4 C, HOTS, serta mengintegrasikan nilai-nilai Al-Qur'an dan Budaya Alam Minangkabau. Namun dalam pelaksanaannya pembelajaran seringkali hanya dilakukan di dalam kelas, belum ditunjang dengan aktivitas peserta didik yang dapat mengarahkan mereka memiliki pengalaman belajar kontektual. Metode pembelajaran yang seringkali digunakan dalam pembelajaran sosiologi adalah diskusi, presentasi, ceramah, kemudian mengukur kemampuan peserta didik melalui tes. Guru sudah melakukan penugasan kepada peserta didik untuk mengamati fenomena di lingkungan sekitarnya yang sesuai dengan materi yang dipelajari di kelas, dan kembali ke kelas untuk menilai peserta didik berdiskusi mengenai laporan mereka, kemudian memberikan soal untuk mengukur kemampuan kognitif peserta didik berupa soal dengan tingkatan kognitif $\mathrm{C} 1$ - C3. Penilaian yang dilakukan dalam pembelajaran Sosiologi SMA/MA menggunakan tes tertulis, seperti ulangan akhir pokok bahasan (KD), ulangan umum dan tugas, baik di kelas ataupun untuk dikerjakan di rumah (100\%). Sedangkan penilaian kinerja pernah dilakukan untuk menilai makalah dan kliping peserta didik, namun tidak terdapat instrumen dan rubrik yang sesuai sebagai acuannya. Penilaian diri belum pernah dilakukan $(0 \%)$, penilaian proyek belum pernah dilakukan $(0 \%)$ dan penilaian portofolio diasumsikan sebagai akumulasi nilai peserta didik untuk setiap tugasnya selama satu semester $(0 \%)$. Penilaian tidak dilakukan secara holistik pada berbagai domain dan sering dilakukan pada akhir pembelajaran. Artinya guru sudah merancang pembelajaran dengan berbagai model yang bervariasi namun pelaksanaan pembelajaran tetap fokus pada domain kognitif peserta didik khususnya penguasaan materi. Tanpa melakukan penilaian akurat yang untuk mengukur domain afektif dan psikomotor, sulit bagi guru untuk mengevaluasi kompetensi peserta didik dan mendapatkan feed back agar dapat melakukan perbaikan terhadap kualitas pembelajarannya.

Hagstrum (2006) mengungkapkan bahwa peningkatan kualitas pendidikan memerlukan perbaikan proses pembelajaran di sekolah dengan menerapkan cara kerja sistematis, salah satu diantaranya dapat dimulai dari pembenahan sistem asesmen (penilaian). Pendapat ini mengandung makna bahwa untuk memperbaiki sistem pembelajaran di sekolah, diperlukan sejumlah informasi dari hasil kegiatan asesmen yang dilakukan secara sistematis dan profesional oleh guru, sekolah, maupun institusi pendidikan yang lain.

Jurnal Socius: Journal of Sociology Research and Education Vol. 6, No.2, Th. 2019 
Permasalahan utama yang dihadapi guru sosiologi saat ini adalah kesulitan guru menghubungkan konsep/tema/pokok bahasan dengan lingkungan kehidupan peserta didiknya. Hal tersebut membuat peserta didik belum merasakan kebermaknaan (meaningfullness) dari kegiatan pembelajaran yang diperolehnya, sehingga materi yang dibelajarkan tidak tersimpan ke dalam memori jangka panjang (long term memory) peserta didik, sehingga sulit tercapai peserta didik yang memiliki penguasaan pengetahuan mengenai ilmu sosiologi, nilai kemanusiaan dan keterlibatan sosial di masyarakat.

Keadaan di atas menggambarkan ada ketidakcocokan antara rencana pelaksanaan pembelajaran yang telah dirancang, proses pembelajaran yang telah dilakukan dengan teknik penilaian yang digunakan. Proses penilaian umum yang dilakukan oleh para guru hanya cukup untuk menggambarkan penguasaan konsep siswa, sehingga tujuan pembelajaran sosiologi SMA belum tercapai. Meskipun guru menyadari penilaian autentik sangat penting, namun sulit dilaksanakan oleh guru karena belum tersedianya instrumen penilaian autentik yang sesuai dengan materi beserta pedoman penggunaannya. Oleh karena itu, guru perlu memiliki instrumen penilaian autentik yang sejalan dengan proses pembelajarannya untuk mengukur domain kognitif, afektif dan psikomotor peserta didik agar dapat dilaksanakan untuk menilai proses, produk dan hasil belajar, sehingga perlu dikembangkan instrumen penilaian autentik yang dapat digunakan pada pembelajaran sosiologi SMA.

Menurut John Mueller (2008): Assessment Authentic: A form of assessment in which students are asked to perform real-world tasks that demontrate meaningfull application of essential knowledge and skills. Asesmen autentik adalah suatu tipe/bentuk asesmen dimana peserta didik melakukan, menerapkan dan atau melaksanakan suatu tugas dalam kehidupan nyata/riil, bukan hanya dengan tes` tertulis di akhir kegiatan belajar saja. Penilaian autentik dapat dilakukan dalam berbagai bentuk, sesuai dengan tujuan pembelajaran, antara lain berupa: observasi, penilaian diri, porfolio, tugas autentik, experimen, diskusi terfokus, jurnal, analisis terhadap peristiwa, berkolaborasi dengan antar sesama melalui debat, dan ekshibisi. Oleh karena itu, Penilaian autentik tidak hanya menilai tingkah laku yang diinginkan, tetapi juga sikap, pengetahuan, keterampilan sesuai dengan kompetensi, proses mengerjakan, serta dalam konteks kehidupan nyata, sebagai bagian integral dari proses pembelajaran. Kehidupan riil/nyata yang dimaksud dapat berupa kehidupan peserta didik di sekolah atau kehidupan dalam masyarakat.

Suatu penilaian dianggap autentik ketika guru langsung menguji peserta didik dengan tugas intelektual yang terpercaya (Wiggins, 1990, p.1). Hal ini sejalan dengan pendapat yang disampaikan oleh Nitko \& Brookhart (2011, pp.246-247) bahwa arti kata autentik dalam penilaian autentik adalah menyajikan tugas secara langsung kepada peserta didik yang berarti sesuai dengan kehidupan nyata sehingga pendidikan bagi mereka bermakna.

Artikel ini bertujuan mendeskripsikan hasil penelitian mengenai (1) karakteristik instrumen penilaian autentik dalam pembelajaran sosiologi SMA yang dikembangkan, (2) kelayakan instrumen penilaian autentik yang memenuhi persyaratan penilaian dari aspek validitas dan reliabilitas, serta (3) pencapaian kompetensi sosiologi dan kemampuan $4 \mathrm{C}$ (critical thinking and problem solving, collaboration, communication, creative and innovative thinking skill) dan HOTS peserta didik setelah dinilai menggunakan instrumen penilaian autentik berbasis authentic inquiry learning khususnya pada materi masalah sosial di masyarakat. 


\section{Metode Penelitian}

Penelitian ini merupakan penelitian research and development. Produk yang dikembangkan adalah instrumen penilaian autentik dalam mata pelajaran Sosiologi di SMA yang terdiri dari instrumen penilaian kognitif (soal tes), penilaian sikap (spiritual dan sosial) berupa instrumen penilaian diri dan teman sejawat, penilaian keterampilan (penilaian kinerja, proyek), serta pedoman observasi diskusi kelas dan kunjungan lapangan. Model pengembangan yang digunakan adalah model pengembangan ADDIE, dengan tahapan Analysis, Design, Development, Implementation, dan Evaluation. Data dikumpulkan melalui observasi, wawancara, kuesioner, dan tes untuk menghasilkan instrumen penilaian autentik yang valid, praktis dan efektif. Untuk mengetahui validitas isi, konstruk, bahasa, instrumen autentik ini telah divalidasi oleh 4 orang ahli baik dari segi evaluasi pembelajaran, konten materi sosiologi, maupun bahasa.

Data kelayakan instrumen penilaian autentik dianalisis menggunakan formula $\mathrm{V}$ Aikend's, serta menggunakan koefisien reliabilitas Alpha Cronbach untuk menguji reliabilitas instrumen. Untuk mengetahui efektifitas instrumen penilaian autentik ujicobakan secara terbatas pada pembelajaran sosiologi materi masalah sosial dalam masyarakat berbasis authentic inquiry learning pada peserta didik kelas XI IIS SMA N 1 Padang semester JuliDesember 2019 yang terdiri dari 35 peserta didik.

\section{Hasil dan Pembahasan}

Pendekatan authentic inquiry learning merupakan perpaduan tahapan antara authentic learning dan pendekatan inquiry.(Hume \& Coll, 2010). Authentic inquiry learning merupakan pendekatan pembelajaran yang dimulai dari ketertarikan dan pengalaman peserta didik, berawal dari obyek yang konkrit sebagai proses memfasilitasi peserta didik untuk dapat membangun pengetahuan. Pendekatan pembelajaran ini melibatkan peserta didik untuk berperan dalam aktivitas pembelajaran secara nyata, selanjutnya peserta didik dapat melakukan penyelidikan, menuntut peserta didik berperan aktif membangun pengetahuan dari lingkungan sekitarnya. Tahapan pendekatan authentic inquiry learning yaitu masalah kontekstual, kolaborasi, penggunaan variasi sumber belajar, dan kegiatan investigasi. Kegiatan investigasi merupakan tahapan inquiry yaitu merumuskan masalah, merumuskan hipotesis, merancang eksperimen, menemukan data, dan menarik kesimpulan sementara. Keunggulan dari authentic inquiry learning dapat mendorong peserta didik untuk mengembangkan self concept, bakat dan kecakapan individu, memberikan kesempatan peserta didik menemukan kebebasan cara belajarnya, kemampuan pemecahan masalah dan sikap ingin tahu peserta didik serta merefleksikannya dalam kehidupan sehari-hari.

Penilaian autentik berbasis authentic inquiry learning merupakan teknik penilaian yang terintegrasi pada proses pembelajaran sehingga proses penilaian dilakukan pada proses dan akhir pembelajaran. Instrumen penilaian autentik dalam pembelajaran sosiologi yang dikembangkan ini diharapkan dapat digunakan untuk mengakses kemajuan belajar siswa sehingga guru dapat memodifikasi pembelajaran disesuaikan dengan kebutuhan nyata siswa mereka.

\section{Karaktersitik Instrumen Penilaian Autentik Pada Pembelajaran Sosiologi}

Hasil analisis awal diperoleh data bahwa instrumen penilaian yang digunakan dalam pembelajaran sosiologi, belum sesuai dengan standar penilaian proses dan hasil belajar peserta didik berdasarkan kurikulum 2013. Hal ini dapat dilihat dari belum tersedianya rubrik penilaian yang memuat indikator pengukuran, deskriptor pengukuran, dan bobot skor, yang dijadikan 
sebagai dasar pengukuran kemampuan peserta didik dalam memecahkan masalah pada setiap aspek kompetensi. Adapun instrumen penilaian autentik yang dikembangkan bertujuan dapat mengukur perkembangan domain afektif, kognitif, dan psikomotorik peserta didik dan dilaksanakan bersinergi dengan proses pembelajaran berbasis authentic inquiry learning, yang terdiri dari penilaian kinerja dan penilaian sikap dilakukan saat proses penyelidikan ilmiah dan pembuatan proyek, sedangkan penilaian pengetahuan dilakukan pada akhir kegiatan penyelidikan ilmiah yang menghasilkan proyek laporan penelitian. Seluruh jenis penilaian autentik berbasis authentic inquiry learning ini menggunakan rentang penilaian 1-4 untuk memudahkan penilaian dan pelaporan hasil belajar sesuai dengan kurikulum 2013. Berdasarkan hasil analisis tersebut, peneliti melakukan analisis kebutuhan terhadap sasaran penilaian, teknik dan bentuk penilaian, serta format instrumen penilaian yang sesuai dengan standar penilaian proses dan hasil belajar peserta didik kurikulum 2013. Karakteristik instrumen penilaian autentik yang dikembangkan dapat dilihat di bawah ini;

Tabel 1. Karakteristik Instrumen Penilaian Autentik pada Pembelajaran Sosiologi SMA

\begin{tabular}{|c|c|c|c|}
\hline $\begin{array}{c}\text { Aspek } \\
\text { Kompetensi }\end{array}$ & Sasaran Penilaian & Teknik Penilaian & Bentuk Instrumen \\
\hline Sikap & $\begin{array}{l}\text { Nilai } \\
\text { Menginternalisasi } \\
\text { Karakter }\end{array}$ & $\begin{array}{l}\text { Penilaian Diri } \\
\text { Penilaian Teman Sejawat } \\
\text { Penilaian Unjuk Kerja }\end{array}$ & $\begin{array}{l}\text { Lembar observasi } \\
\text { tertutup } \\
\text { Pernyataan Sikap } \\
\text { Pernyataan Sikap }\end{array}$ \\
\hline Pengetahuan & $\begin{array}{l}\text { Mengingat } \\
\text { Memahami } \\
\text { Menerapkan } \\
\text { Mengevaluasi } \\
\text { Mencipta } \\
\end{array}$ & $\begin{array}{l}\text { Tes Tertulis } \\
\text { Penugasan }\end{array}$ & $\begin{array}{l}\text { Soal pilihan ganda } \\
\text { Lembar kerja }\end{array}$ \\
\hline $\begin{array}{l}\text { Keterampilan } \\
\text { Abstrak }\end{array}$ & $\begin{array}{l}\text { Mengamati } \\
\text { Mengolah } \\
\text { Menyaji } \\
\text { Menalar } \\
\end{array}$ & $\begin{array}{l}\text { Penilaian Kinerja } \\
\text { Penilaian Proyek }\end{array}$ & $\begin{array}{l}\text { Rubrik Unjuk Kerja } \\
\text { Rubrik Penilaian Proyek }\end{array}$ \\
\hline $\begin{array}{l}\text { Keterampilan } \\
\text { Konkret }\end{array}$ & $\begin{array}{l}\text { Persepsi } \\
\text { Kesiapan } \\
\text { Meniru } \\
\text { Membiasakan } \\
\text { Menjadi tindakan orisional }\end{array}$ & $\begin{array}{l}\text { Penilaian Kinerja } \\
\text { Penilaian Proyek } \\
\text { Penilaian Presentasi }\end{array}$ & $\begin{array}{l}\text { Rubrik Unjuk Kerja } \\
\text { Rubrik Penilaian Proyek } \\
\text { Rubrik observasi } \\
\text { lapangan }\end{array}$ \\
\hline
\end{tabular}

(Sumber : Analisis Pengembangan Konseptua, Ike Sylvia, 2019)

Instrumen penilaian autentik berbasis authentic inquiry learning yang dikembangkan terdiri dari:

\section{Penilaian Kinerja}

Penilaian kinerja dilakukan secara individu pada saat peserta didik merencanakan dan mengerjakan proyek secara autentik. Aspek yang dinilai dalam penilaian kinerja dimulai dari perencanaan proyek, penggunaan alat indera yang sesuai saat observasi, pembuatan desain rancangan proyek, penentuan hipotesis, metode dan prosedur yang digunakan, penentuan indikator fenomena yang diamati, keterampilan penggunaan alat dan bahan untuk pengumpulan data, cara penampilan data dalam laporan, analisis data, hingga kesimpulan proyek.

\section{Penilaian Sikap}

Penilaian sikap menilai sikap peserta didik pada saat pembelajaran authentic inquiry learning berlangsung. Aspek penilaian sikap meliputi sikap religius dan sikap sosial. Aspek

Jurnal Socius: Journal of Sociology Research and Education Vol. 6, No.2, Th. 2019 
penilaian sikap sosial meliputi kerjasama, antusias, tanggung jawab, mandiri, dan merespon. Masing-masing aspek penialain dilengkapi dengan rubrik untuk memudahkan penilaian dan menghindari unsur subjektivitas penilaian.

\section{Penilaian Presentasi}

Penilaian presentasi dilakukan pada saat peserta didik mempresentasikan produk proyek mereka di depan kelas. Aspek penilaian terbagi menjadi dua yaitu isi presentasi dan penampilan presentasi. Isi presentasi yang dinilai meliputi penjelasan konsep sosiologi yang berkaitan dengan produk proyek peserta didik, penjelasan cara kerja, demonstrasi hasil temuan/produk proyek, dan kesimpulan. Adapun penampilan presentasi dinilai dari kualitas suara, antusias peserta didik dalam presentasi, bahasa tubuh seperti kontak mata terhadap audience.

\section{Penilaian Produk Proyek}

Aspek penilaian produk proyek meliputi keaslian proyek yang dibuat, kerapihan, konsep sosiologi yang terdapat dalam produk laporan proyek, kebermaknaan produk proyek dalam kehidupan nyata, daya tarik laporan produk proyek, dan inovasi yang dilakukan peserta didik.

\section{Penilaian Pengetahuan}

Penilaian pengetahuan digunakan untuk mengetahui berapa dalam pengetahuan yang bisa diserap peserta didik melalui pembelajaran berbasis authentic inquiry learning. Penilaian pengetahuan dimaksudkan untuk melihat kemampuan peserta didik menampilkan kemampuan dalam menulis, mengorganisasikan, mengekspresikan dan menjelaskan hubungan antar ide sehingga mampu menilai kemampuan berpikir tingkat tinggi peserta didik.

\section{Kelayakan Instrumen Penilaian Autentik untuk Pembelajaran Sosiologi}

Pengembangan instrumen penilaian autentik pada mata pelajaran sosiologi dilaksanakan melalui beberapa tahapan, sesuai dengan langkah-langkah model pengembangan ADDIE. Pada tahap Analisis (Analysis), peneliti menganalisis pelaksanaan dan instrumen penilaian yang telah digunakan di SMA melalui MGMP Sosiologi SMA baik ditingkat provinsi maupun Kota Padang, melakukan diskusi dengan guru mata pelajaran sosiologi tentang penilaian yang digunakan, dan mengidentifikasi kebutuhan guru agar dapat melaksanakan proses pembelajaran dan penilaian yang holistik. Data tersebut digunakan sebagai pertimbangan dalam pengembangan instrumen penilaian autentik berbasis authentic inquiry learning yang sesuai dengan karakteristik peserta didik SMA, macam penilaian yang digunakan, serta media, alat, dan bahan yang diperlukan dalam melakukan pembelajaran yang autentik. Keseluruhan kebutuhan tersebut kemudian disesuaikan dengan silabus pada kurikulum 2013. Dalam penelitian ini pendekatan authentic inquiry learning dan penilaian autentik diujicobakan pada materi sosiologi kelas XI yaitu masalah sosial dalam masyarakat.

Setalah tahap analisis kebutuhan selesai, tahap selanjutnya adalah merancang instrumen penilaian autentik berdasarkan kisi-kisi pada kajian teori. Pada tahap Desain (Design), peneliti merencanakan jadwal pembuatan produk dan menentukan tim validasi ahli yang terdiri dari empat orang validator ahli, empat orang guru mata pelajaran sosiologi. Selain itu pada tahap ini peneliti menyusun spesifikasi produk instrumen penilaian yang dikembangkan, berdasarkan sasaran penilaian, teknik penilaian, dan bentuk penilaian untuk setiap aspek kompetensi peserta didik. Penilaian pada saat proses pembelajaran berupa penilaian kinerja dan penilaian sikap, sedangkan penilaian hasil berupa penilaian presentasi, penilaian proyek, dan penilaian pengetahuan. Untuk menunjang penilaian tersebut dirancang media pembelajaran berupa lembar perencanaan proyek untuk memandu peserta didik dalam melakukan investigasi dan proyek yang sesuai dengan minat mereka serta lembar kerja proyek

Jurnal Socius: Journal of Sociology Research and Education Vol. 6, No.2, Th. 2019

ISSN: Online 2442-8663 - Print 2356-4180 
untuk memandu kerja peserta didik dalam penyelidikan ilmiah agar proyek tugas sesuai dengan metode ilmiah. Untuk terlaksananya pembelajaran efektif dan efisien dibuat rencana pelaksanaan pembelajaran sesuai kurikulum 2013 berbasis pendekatan authentic inquiry learning, dengan mengakomodasi kemampuan $4 \mathrm{C}$ dan HOTS peserta didik.

Spesifikasi desain yang dihasilkan meliputi bentuk instrumen, bobot skor, dan jumlah item penilaian. Adapun komponen kemampuan $4 C$ peserta didik yang dikembangkan dalam penelitian ini adalah sebagai tabel 3 berikut :

Tabel 2. Pengembangan Indikator Kemampuan 4 C

\begin{tabular}{|c|c|c|c|c|}
\hline $\begin{array}{c}\text { Kemampuan } \\
\text { yang } \\
\text { dikembangkan }\end{array}$ & $\begin{array}{c}\text { Komunikasi } \\
\text { (Communication) }\end{array}$ & $\begin{array}{c}\text { Kolaboratif } \\
\text { (Collaboration) }\end{array}$ & $\begin{array}{c}\text { Berfikir Kritis dan } \\
\text { Pemecahan Masalah } \\
\text { (Critical Thinking } \\
\text { and Problem Solving) }\end{array}$ & $\begin{array}{l}\text { Kreatifitas dan } \\
\text { Inovasi (Cretivity } \\
\text { and Inovation) }\end{array}$ \\
\hline Indikator & $\begin{array}{l}\text { - Mendemonstrasi } \\
\text { kan } \\
\text { - Bertukar } \\
\text { pikiran dan } \\
\text { menjelaskan } \\
\text { ide }\end{array}$ & $\begin{array}{l}\text { - Bekerja dalam } \\
\text { kelompok } \\
\text { - Berdiskusi } \\
\text { - Mentrasformasi } \\
\text { kan ide } \\
\text { - Mendengarkan }\end{array}$ & $\begin{array}{l}\text { - Mengidentifikasi- } \\
\text { kan masalah } \\
\text { - Merumuskan } \\
\text { masalah } \\
\text { - Mengevaluasi } \\
\text { kinerja } \\
\text { - Menentukan pilihan } \\
\text { - Menganalisis }\end{array}$ & $\begin{array}{l}\text { - Membandingkan } \\
\text { - Mengevaluasi } \\
\text { - Mengkontribusika } \\
\text { n ide-ide ke dalam } \\
\text { dunia nyata } \\
\text { - Menyelesaikan } \\
\text { masalah }\end{array}$ \\
\hline
\end{tabular}

(Sumber: Analisis Pengembangan Konseptual, Ike Sylvia, 2019)

Pada tahap pengembangan (development), dirancang produk serta aktivitas yang akan dilaksanakan guru dan siswa pada proses pembelajaran serta instrumen yang akan digunakan Pembuatan instrumen penilaian autentik dirancang sesuai dengan aktivitas pembelajaran berbasis pendekatan authentic inquiry learning, sehingga spesifikasi dan produk instrumen yang dihasilkan lengkap dengan rubriknya dan didapat digunakan pada pembelajaran sosiologi pada materi lainnya. Masing-masing aspek penilaian tersebut dibuat gradasi skor tertinggi sampai terendah (4-1). Setelah rancangan produk penilaian autentik berbasis authentic inquiry learning selesai dikembangkan, langkah selanjutnya adalah menguji validitas instrumen dengan melakukan validasi isi (content validity) kepada ahli. Validasi ini untuk menilai format penampilan dan mampu mengungkap apa yang akan diukur (face validity), dan isi tes yang mempresentasikan ciri-ciri atribut yang hendak diukur. Instrumen yang divalidasi meliputi RPP, LKPD (lembar perencanaan proyek dan lembar kerja proyek), dan instrumen penilaian autentik berbasis pendekatan authentic inquiry learning (penilaian kinerja, penilaian sikap, penilaian presentasi, penilaian produk proyek, dan penilaian pengetahuan). Validitas dianalisis menggunakan formula V Aikend's. Hasil analisis serta interpretasi validitas instrumen penilaian autentik berbasis authentic inquiry learning dapat dilihat pada tabel berikut.

Tabel 3. Hasil Analisis Validitas Instrumen Penilaian Autentik Berbasis Authentic Inquiry Learning

\begin{tabular}{|c|c|c|c|}
\hline No & Instrumen & Rerata Nilai V & Interpretasi \\
\hline 1 & RPP & 0,804 & Validitas Tinggi \\
\hline 2 & LKPD & 0,824 & Validitas Tinggi \\
\hline 3 & Penilaian Kinerja & 0,813 & Validitas Tinggi \\
\hline 4 & Penilaian Sikap & 0,833 & Validitas Tinggi \\
\hline 5 & Penilaian Presentasi & 0,833 & Validitas Tinggi \\
\hline 6 & Penilaian Proyek & 0,833 & Validitas Tinggi \\
\hline
\end{tabular}

Jurnal Socius: Journal of Sociology Research and Education Vol. 6, No.2, Th. 2019

ISSN: Online 2442-8663 - Print 2356-4180 


\begin{tabular}{llcc}
\hline 7 & Penilaian Pengetahuan & 0,833 & Validitas Tinggi \\
\hline & Rerata & $\mathbf{0 , 8 2 9}$ & Validitas Tinggi \\
\hline
\end{tabular}

(Sumber: Pengolahan data primer, 2019)

Hasil penilaian ahli terhadap aspek validitas, kebahasaan dan praktikalitas dari ketiga instrumen penilaian yang dikembangkan sudah sesuai dan layak secara keseluruhan. Kriteria kelayakan instrumen penilaian autentik berbasis proyek dinilai dari tingkat validitas, didapatkan rerata isi V Aikend's sebesar 0,829 atau interpretasi tinggi. Pada tahap implementasi (implementation), instrumen penilaian yang telah direvisi dan dinyatakan layak oleh ahli, kemudian diujicobakan secara terbatas di kelas XI IS SMA Negeri 1 Padang dengan subjek 35 orang peserta didik. Proses pembelajaran dan penilaian dilaksanakan sesuai dengan tahapan pembelajaran authentic inquiry learning. Aktivitas peserta didik dan jenis penilaian yang dilakukan oleh guru pada materi masalah sosial di masyarakat dapat dilihat pada tabel di bawah ini.

Tabel 4. Aktivitas Kegiatan Pembelajaran Authentic Inquiry Learning dan Jenis Penilaian Autentik yang Dilaksanakan

\begin{tabular}{|c|c|c|c|}
\hline No & $\begin{array}{c}\text { Komponen } \\
\text { Authentic Inquiry } \\
\text { Learning }\end{array}$ & Aktivitas Peserta didik & Jenis Penilaian \\
\hline 1 & $\begin{array}{l}\text { Menemukan } \\
\text { masalah } \\
\text { kontekstual }\end{array}$ & $\begin{array}{l}\text { Melakukan observasi dan menemukan } \\
\text { fenomena masalah sosial yang ada di } \\
\text { masyarakat, yaitu tindakan kriminal, } \\
\text { kemiskinan, kenakalan remaja, } \\
\text { kesenjangan sosial, cyber crime dan } \\
\text { penyimpangan seksual }\end{array}$ & $\begin{array}{l}\text { Penilaian Sikap } \\
\text { Penilaian Kinerja }\end{array}$ \\
\hline 2 & Kolaborasi & $\begin{array}{l}\text { Berkolaborasi untuk mencoba } \\
\text { mengamati, menemukan data awal } \\
\text { mengenai penyebab timbulnya berbagai } \\
\text { masalah sosial tersebut. }\end{array}$ & $\begin{array}{l}\text { Penilaian Sikap } \\
\text { Penilaian Kinerja }\end{array}$ \\
\hline 3 & $\begin{array}{l}\text { Penggunaan } \\
\text { variasi sumber } \\
\text { belajar }\end{array}$ & $\begin{array}{l}\text { Melakukan literasi dari berbagai sumber } \\
\text { untuk menemukan dokumen dan } \\
\text { melakukan perbandingan penyebab } \\
\text { timbulnya tindakan kriminal, kemiskinan, } \\
\text { kenakalan remaja, kesenjangan sosial, } \\
\text { cyber crime dan penyimpangan seksual di } \\
\text { masyarakat, melaporkan kemajuan } \\
\text { aktivitas penyelelidikan di kelas }\end{array}$ & $\begin{array}{l}\text { Penilaian Kinerja } \\
\text { Penilaian Presentasi }\end{array}$ \\
\hline 4 & $\begin{array}{l}\text { Merumuskan } \\
\text { masalah } \\
\text { (pertemuan } \\
\text { pertama) }\end{array}$ & $\begin{array}{l}\text { Merumuskan masalah yang akan diteliti } \\
\text { oleh peserta didik sehubungan dengan } \\
\text { penyebab timbulnya tindakan kriminal, } \\
\text { kemiskinan, kenakalan remaja, } \\
\text { kesenjangan sosial, cyber crime dan } \\
\text { penyimpangan seksual di masyarakat, } \\
\text { melaporkan kemajuan aktivitas } \\
\text { penyelelidikan di kelas }\end{array}$ & $\begin{array}{l}\text { Penilaian Sikap } \\
\text { Penilaian Kinerja } \\
\text { Penilaian Proyek } \\
\text { Penilaian Pengetahuan }\end{array}$ \\
\hline 5 & $\begin{array}{l}\text { Merumuskan } \\
\text { hipotesis } \\
\text { (pertemuan kedua) }\end{array}$ & $\begin{array}{l}\text { Merumuskan hipotesis penyebab } \\
\text { timbulnya tindakan kriminal, kemiskinan, } \\
\text { kenakalan remaja, kesenjangan sosial, } \\
\text { cyber crime dan penyimpangan seksual di }\end{array}$ & $\begin{array}{l}\text { Penilaian Sikap } \\
\text { Penilaian Kinerja } \\
\text { Penilaian Proyek } \\
\text { Penilaian Pengetahuan } \\
\end{array}$ \\
\hline
\end{tabular}

Jurnal Socius: Journal of Sociology Research and Education Vol. 6, No.2, Th. 2019 


\begin{tabular}{|c|c|c|c|}
\hline & & $\begin{array}{l}\text { masyarakat, melaporkan kemajuan } \\
\text { aktivitas penyelelidikan di kelas }\end{array}$ & \\
\hline 6 & $\begin{array}{l}\text { Merancang } \\
\text { eksperimen } \\
\text { (pertemuan kedua) }\end{array}$ & $\begin{array}{l}\text { Merancang proyek dan menentukan } \\
\text { teknik pengumpulan data dalam bentuk } \\
\text { observasi dan wawancara kepada } \\
\text { informan terkait topik tindakan kriminal, } \\
\text { kemiskinan, kenakalan remaja, } \\
\text { kesenjangan sosial, cyber crime dan } \\
\text { penyimpangan seksual, melaporkan } \\
\text { kemajuan aktivitas penyelelidikan di } \\
\text { kelas }\end{array}$ & $\begin{array}{l}\text { Penilaian Sikap } \\
\text { Penilaian Kinerja } \\
\text { Penilaian Proyek } \\
\text { Penilaian Pengetahuan }\end{array}$ \\
\hline 7 & $\begin{array}{l}\text { Menemukan data } \\
\text { (pertemuan ketiga) }\end{array}$ & $\begin{array}{l}\text { Malaksanakan proyek dan } \\
\text { mengumpulkan data melalui observasi } \\
\text { dan wawancara kepada informan serta } \\
\text { melakukan triangulasi data dengan } \\
\text { sumber yang relevan, melaporkan } \\
\text { kemajuan aktivitas penyelidikan di kelas }\end{array}$ & $\begin{array}{l}\text { Penilaian Sikap } \\
\text { Penilaian Kinerja } \\
\text { Penilaian Proyek } \\
\text { Penilaian Pengetahuan }\end{array}$ \\
\hline 8 & $\begin{array}{l}\text { Menarik } \\
\text { kesimpulan } \\
\text { sementara } \\
\text { (pertemuan } \\
\text { keempat) }\end{array}$ & $\begin{array}{l}\text { Menyusun laporan penelitian sebagai } \\
\text { produk proyek terkait topik penyebab } \\
\text { timbulnya masalah sosial di masyarakat } \\
\text { dan mempresentasikannya di kelas, } \\
\text { melaporkan kemajuan aktivitas } \\
\text { penyelelidikan di kelas }\end{array}$ & $\begin{array}{l}\text { Penilaian Sikap } \\
\text { Penilaian Kinerja } \\
\text { Penilaian Proyek } \\
\text { Penilaian Pengetahuan }\end{array}$ \\
\hline
\end{tabular}

(Sumber : Analisis Pengembangan Konseptual, Ike Sylvia, 2019)

Hasil penilaian kemudian diuji reliabilitasnya. Adapun rerata reliabilitas Alpha Cronbach sebesar 0,697 atau interpretasi tinggi. Hal tersebut menunjukkan bahwa instrumen penilaian autentik berbasis authentic inquiry learning yang dikembangkan mampu mendapatkan hasil yang konsisten jika digunakan untuk menilai kemampuan peserta didik secara berulang. Berikut disajikan hasil reliabilitas sertai interpretasinya.

\section{Tabel 5. Hasil Analisis Reliabilitas Instrumen Penilaian Autentik Berbasis Authentic} Inquiry Learning

\begin{tabular}{clcl}
\hline No & Instrumen & $\begin{array}{c}\text { Koefisien } \\
\text { Reliabilitas Alpha } \\
\text { Cronbach }\end{array}$ & \multicolumn{1}{c}{ Interpretasi } \\
\hline 1 & Penilaian Kinerja & 0,780 & Reliabilitas Tinggi \\
\hline 2 & Penilaian Sikap & 0,615 & Reliabilitas Sedang \\
\hline 3 & Peneilaian Presentasi & 0,752 & Reliabilitas Tinggi \\
\hline 4 & Penilaian Produk Proyek & 0,643 & Reliabilitas Sedang \\
\hline & Rerata & $\mathbf{0 , 6 9 7}$ & Reliabilitas Tinggi \\
\hline
\end{tabular}

(Sumber : Pengolahan data primer, 2019)

Berdasarkan hasil analisis validitas dan reliabilitas instrumen penilaian autentik yang dikembangkan, instrumen ini dinyatakan layak dan konsisten untuk mengukur domain kognitif, afektif dan psikomotor siswa. Untuk mengetahui efektifitas produk, instrumen ini diujicobakan secara terbatas melibatkan guru Sosiologi dan 35 orang peserta didik kelas XI IS SMA Negeri 1 Kota Padang sebagai subjek ujicoba. Uji coba instrumen penilaian autentik ini berlangsung selama empat pertemuan sesuai dengan topik materi masalah sosial, pembelajaran yang 
dilaksanakan telah dirancang sesuai dengan pendekatan authentic inquiry learning yaitu tahap perencanaan, pengumpulan data, pelaporan dan umpan balik dari penyelidikan.

Aktivitas pembelajaran yang berlangsung sesuai dengan langkah-langkah penyelidikan ilmiah pada setting real fenomena masalah sosial yang ada di masyarakat. Sehingga instrumen penilaian autentik dapat digunakan. Peserta didik bekerja dalam tim beranggotakan enam orang untuk perencanaan dan pengumpulan data, namun pelaporan tugas tetap dilakukan secara individu. Peserta didik terlibat merencanakan secara individu untuk setiap topik yang diberikan sebagai tanggung jawab pribadi mereka, dan bekerja sama sebagai anggota kelompok untuk menghasilkan satu rencana dan mendapatkan data, kemudian menulis laporan secara individual. Hal ini dilakukan agar kemajuan aktivitas peserta didik dalam pembelajaran pada domain afektif, kognitif dan psikomotor dapat diperoleh, sehingga guru dapat memberikan umpan balik kepada peserta didik secara individu maupun kelompok di kelas.

Pada akhir pembelajaran berbasis authentic inquiry learning dilakukan penyebaran angket sikap peserta didik berkaitan dengan model penilaian autentik berbasis proyek yang telah dilaksanakan. Penyebaran angket bertujuan mengetahui sikap dan pendapat peserta didik terhadap proses pembelajaran dan penilaian autentik yang dilaksanakan. Hasil angket peserta didik dapat dilihat pada tabel 6.

Tabel 6. Analisis Angket Peserta Didik Terhadap Penilaian Autentik Berbasis Authentic Inquiry Learning

\begin{tabular}{clccc}
\hline \multirow{2}{*}{ No } & \multicolumn{1}{c}{ Pernyataan } & \multicolumn{2}{c}{ Pilihan Sikap } \\
\cline { 2 - 5 } & \multicolumn{1}{c}{$\begin{array}{c}\text { Sangat } \\
\text { Setuju }\end{array}$} & Setuju & Ragu \\
\hline 1 & $\begin{array}{l}\text { Pembelajaran sosiologi berbasis authentic inquiry } \\
\text { learning baru bagi saya }\end{array}$ & 50 & 5 \\
\hline 2 & $\begin{array}{l}\text { Penugasan dalam authentic inquiry learning yang saya } \\
\text { kerjakan sesuai dengan minat dan ketertarikan saya }\end{array}$ & 10 & 66 & 24 \\
\hline 3 & Saya sangat antusias dalam mengerjakan proyek & 14 & 67 & 19 \\
\hline 4 & $\begin{array}{l}\text { Saya ingin menampilkan hasil proyek saya di depan } \\
\text { kelas secara sempurna }\end{array}$ & 24 & 52 & 24 \\
\hline 5 & $\begin{array}{l}\text { Belajar melalui langkah-langkah authentic inquiry } \\
\text { membantu saya memahami konsep-konsep sosiologi }\end{array}$ & 43 & 57 & 14 \\
\hline 6 & $\begin{array}{l}\text { Pembelajaran authentic inquiry learning memberi } \\
\text { makna mendalam dalam kehidupan sehari-hari }\end{array}$ & 24 & 62 \\
\hline 7 & $\begin{array}{l}\text { Pembelajaran authentic inquiry learning melatih } \\
\text { keterampilan berpikir kritis, kreatif saya dan } \\
\text { kolaborasi, komunikasi antar teman }\end{array}$ & 29 & 57 & 14 \\
\hline 8 & $\begin{array}{l}\text { Penilaian autentik yang dilakukan guru benar-benar } \\
\text { menggambarkan kemampuan saya }\end{array}$ & 52 & 33 & 15 \\
\hline 9 & $\begin{array}{l}\text { Saya menginginkan guru melaksanakan penilaian } \\
\text { secara otentik terhadap setiap tugas yang diberikan } \\
\text { pada proses dan akhir pembelajaran sosiologi }\end{array}$ & 57 & 38 & 5 \\
\hline 10 & $\begin{array}{l}\text { Saya menginginkan pembelajaran sosiologi } \\
\text { dilaksanakan dengan kontekstual untuk materi-materi } \\
\text { lainnya }\end{array}$ & 53 & 47 & 0 \\
\hline
\end{tabular}

(Sumber : Pengolahan data primer, 2019) 
Berdasarkan angket peserta didik tersebut terlihat bahwa penilaian autentik berbasis authentic inquiry learning memberikan sikap yang sangat positif dari peserta didik. Hasil angket yang positif menunjukkan bahwa meskipun penilaian autentik berbasis authentic inquiry learning merupakan hal yang baru, tetapi antusias peserta didik dalam melaksanakan pembelajaran tinggi. Peserta didik juga banyak merasakan manfaat dari pembelajaran authentic inquiry learning dan penilaian autentik untuk mengembangkan keterampilan berpikir kritis, problem solving, komunikasi, kolaborasi dan kreatif mereka. Berdasarkan hasil validitas dan reliabilitas instrumen penilaian autentik berbasis authentic inquiry learning dapat dikatakan layak untuk diterapkan.

\section{Pencapaian Kompetensi Sosiologi Peserta Didik Menggunakan Instrumen Penilaian Autentik Berbasis Authentic Inquiry Learning}

Tahap pengembangan produk selanjutnya adalah implementasi (implementation). Pada tahapan ini instrumen penilaian autentik berbasis authentic inquiry learning diujicoba secara terbatas pada kelas XI IS di SMAN 1 Padang materi masalah sosial dalam masyarakat telah menghasilkan data sebagai berikut.

Tabel 7. Pencapaian Kompetensi Sosiologi Peserta Didik Pada Materi Masalah Sosial di Masyarakat Kelas XI IS SMAN 1 Padang

\begin{tabular}{clccccc}
\hline \multirow{2}{*}{ No } & Nama Peserta Didik & Pengetahuan & Sikap & Kinerja & Presentasi & $\begin{array}{c}\text { Produk } \\
\text { Proyek }\end{array}$ \\
\cline { 5 - 7 } & & & & & & Keterampilan \\
\hline 1 & Peserta Didik 1 & 3.2 & 3.6 & 3.1 & 3.6 & 3.4 \\
\hline 2 & Peserta Didik 2 & 2.7 & 3.2 & 2.9 & 3.2 & 3.3 \\
\hline 3 & Peserta Didik 3 & 3.3 & 3.6 & 3 & 3.4 & 3.4 \\
\hline 4 & Peserta Didik 4 & 3.4 & 4 & 3.2 & 3.2 & 3.3 \\
\hline 5 & Peserta Didik 5 & 2.8 & 3.8 & 2.8 & 3 & 3 \\
\hline 6 & Peserta Didik 6 & 3.4 & 3.4 & 2.9 & 3 & 3 \\
\hline 7 & Peserta Didik 7 & 3.4 & 3.6 & 3 & 3 & 3.3. \\
\hline 8 & Peserta Didik 8 & 3.2 & 3.8 & 3 & 3.2 & 3.4 \\
\hline 9 & Peserta Didik 9 & 3.5 & 3.4 & 3 & 3.1 & 3.4 \\
\hline 10 & Peserta Didik 10 & 2.7 & 3.4 & 2.9 & 3.1 & 3.4 \\
\hline 11 & Peserta Didik 11 & 2.7 & 3.4 & 2.9 & 3.6 & 3.4 \\
\hline 12 & Peserta Didik 12 & 2.9 & 3.4 & 2.9 & 3.1 & 3,3 \\
\hline 13 & Peserta Didik 13 & 3.4 & 3.8 & 2.7 & 2.9 & 3.3 \\
\hline 14 & Peserta Didik 14 & 2.7 & 3.4 & 2.9 & 2.9 & 3 \\
\hline 15 & Peserta Didik 15 & 2.6 & 3.4 & 3.1 & 2.8 & 2.7 \\
\hline 16 & Peserta Didik 16 & 2.9 & 3.4 & 2.8 & 2.4 & 3 \\
\hline 17 & Peserta Didik 17 & 3.2 & 3.4 & 3.2 & 2.2 & 3.2 \\
\hline 18 & Peserta Didik 18 & 2.8 & 3.4 & 3.2 & 2.9 & 3 \\
\hline 19 & Peserta Didik 19 & 2.6 & 3.3 & 3.2 & 3 & 3.2 \\
\hline 20 & Peserta Didik 20 & 3.3 & 3.4 & 2.9 & 3 & 3 \\
\hline 21 & Peserta Didik 21 & 2.7 & 3.8 & 3.4 & 3.2 & 3.1 \\
\hline 22 & Peserta Didik 22 & 2.8 & 3.4 & 2.8 & 3.1 & 2.9 \\
\hline 23 & Peserta Didik 23 & 3.1 & 3.4 & 3.2 & 3.1 & 3 \\
\hline 24 & Peserta Didik 24 & 3 & 3.4 & 3.3 & 3.1 & 3.2 \\
\hline 25 & Peserta Didik 25 & 3.2 & 3.6 & 3.4 & 3.2 & 3.2 \\
\hline 26 & Peserta Didik 26 & 2.8 & 3.6 & 3.2 & 2.9 & 3 \\
\hline 27 & Peserta Didik 27 & 2.8 & 3.5 & 3 & 3.2 & 3 \\
\hline
\end{tabular}

Jurnal Socius: Journal of Sociology Research and Education Vol. 6, No.2, Th. 2019

ISSN: Online 2442-8663 - Print 2356-4180

Copyright $\odot 2019$, Jurnal Socius 
Ike Sylvia, Syafri Anwar, Khairani Pengembangan Instrumen Penilaian Autentik Berbasis Pendekatan Authentic Inquiry Learning Pada Mata Pelajaran Sosiologi di Sekolah Menengah Atas

\begin{tabular}{ccccccc}
26 & Peserta Didik 28 & 3.1 & 3.5 & 3.1 & 3 & 3 \\
\hline 29 & Peserta Didik 29 & 3.1 & 3.5 & 3.2 & 3 & 3.1 \\
\hline 30 & Peserta Didik 30 & 3 & 3.5 & 3.1 & 3.2 & 3 \\
\hline 31 & Peserta Didik 31 & 3 & 3.4 & 3.2 & 3.1 & 3 \\
\hline 32 & Peserta Didik 32 & 3.1 & 3.5 & 3 & 3.1 & 3 \\
\hline 33 & Peserta Didik 33 & 3.1 & 3.4 & 3.1 & 3 & 3 \\
\hline 34 & Peserta Didik 34 & 3 & 3.5 & 3 & 3.2 & 3.1 \\
\hline 35 & Peserta Didik 35 & 2.8 & 3.5 & 3.2 & 3.1 & 3 \\
\hline & \multirow{2}{*}{ Rata-rata } & $\mathbf{3 . 0}$ & $\mathbf{3 . 5}$ & $\mathbf{3 . 0 5}$ & $\mathbf{3 . 0 6}$ & $\mathbf{2 . 9 4}$ \\
\cline { 4 - 6 } & & & & & $\mathbf{3 . 1}$ & \\
\hline
\end{tabular}

(Sumber : Pengolahan data primer, 2019)

Penilaian pada aspek keterampilan terdiri atas penilaian kinerja, penilaian presentasi dan penilaian produk proyek. Penilaian sikap merupakan gabungan dari penilaian sikap religius dan sosial. Berdasarkan ujicoba hasil instrumen penilaian autentik berbasis authentic inquiry learning di kelas XI IS pada materi masalah sosial dalam masyarakat diperoleh rerata kelas untuk kompetensi sosiologi yaitu penilaian pengetahuan dengan rerata 3,0 (B); penilaian sikap dengan rerata 3,5 $(\mathrm{B}+)$; dan penilaian keterampilan dengan rerata 3,1 (B). Pada pedoman penilaian hasil belajar untuk kurikulum 2013 dijelaskan bahwa ketuntasan belajar pada aspek pengetahuan dan keterampilan ditetapkan dengan skor minimal 2,67 atau B-, sedangkan ketuntasan aspek sikap ditetapkan minimal B. Berdasarkan pedoman tersebut terlihat bahwa seluruh peserta didik tuntas pada aspek sikap dan keterampilan, namun ada 2 peserta didik yang tidak tuntas pada aspek pengetahuan. Peserta didik yang belum tuntas diwajibkan mengikuti program remedial sampai mencapai ketuntasan minimal, sedangkan peserta didik yang telah tuntas bisa mengikuti program pengayaan untuk memperkaya pengetahuan.

Hasil capaian penilaian pengetahuan peserta didik masuk dalam kategori baik, artinya peserta didik mampu menyerap informasi dan pengetahuan yang didapatkannya melalui penyelidikan ilmiah dengan baik. Penilaian pengetahuan dalam bentuk soal pilihan ganda yang mengaplikasikan dunia nyata dalam kehidupan sehari-hari selain menunjukkan kemampuan asli peserta didik juga mampu melatih kemampuan berpikir tingkat tinggi (high order thinking skills).

Capaian rerata nilai keterampilan peserta didik masuk kategori baik, artinya peserta didik secara umum mampu melaksanakan penyelidikan ilmiah dan tugas-tugas autentik dengan baik. Pencapaian penilaian pada aspek keterampilan yang terdiri dari penilaian kinerja, presentasi, dan produk proyek mampu mendesripsikan secara lebih lengkap kemampuan dan karakteristik peserta didik. Melalui nilai tersebut bisa didapatkan informasi tentang kelebihan masingmasing peserta didik dalam melaksanakan tugas-tugas autentik, apakah itu kelebihan dalam hal kinerja, kelebihan dalam mempresentasikan produk, ataupun kelebihan dalam pembuatan produk proyek. Berdasarkan pencapaian kompetensi peserta didik domain sikap peserta didik cenderung tinggi dibandingkan nilai keterampilan dan pengetahuan. Hasil penelitian ini menunjukkan bahwa penilaian autentik berbasis authentic inquiry learning mampu memunculkan sikap positif peserta didik.

Penggunaan instrumen penilaian autentik dalam pembelajaran sosiologi yang diujicobakan secara terbatas materi masalah sosial dalam masyarakat, dapat mengungkap bahwa, pertama pada kecakapan komunikasi (communication) peserta didik lebih baik pada indikator bertukar pikiran dan menjelaskan ide. Kedua pada kecakapan kolaboratif (collaboration) tugas-tugas autentik dapat mendorong berkembangnya kemampuan bekerja dalam kelompok, berdiskusi dan mentrasformasikan ide. Ketiga, pada kecakapan berfikir kritis

Jurnal Socius: Journal of Sociology Research and Education Vol. 6, No.2, Th. 2019

ISSN: Online 2442-8663 - Print 2356-4180 
dan pemecahan masalah (critical thinking and problem solving), instrumen ini mampu mengukur kemampuan; (a) memahami masalah, (b) merencanakan pemecahan masalah, (c) menyelesaikan masalah sesuai rencana, (d) mengevaluasi hasil pemecahan masalah, dan (e) mengkomunikasikan hasil pemecahan masalah. Hasil penilaian terhadap kemampuan problem solving peserta didik, menunjukkan bahwa peserta didik memiliki kemampuan pada kategori baik. Keempat, pada kecakapan kreativitas dan inovasi (creativity and innovation), instrumen ini dapat mengukur semua indikator yang dikembangkan dan paling baik pada aspek mengkontribusikan ide-ide ke dalam dunia nyata.

Terdapat beberapa aspek yang menjadi implikasi dalam penelitian ini, yaitu rancangan pengembangan instrumen penilaian autentik dan dampak penggunaan instrumen penilaian autentik. Pada aspek pertama instrumen penilaian autentik yang dikembangkan sudah sesuai dengan prinsip-prinsip penilaian autentik. Namun, dari sisi implementasi, penilaian autentik akan berdampak positif untuk peningkatan kualitas pembelajaran pengembangan kompetensi peserta didik jika guru juga merancang pembelajaran yang berbasis real setting atau pembelajaran autentik, sehingga peserta didik dapat merasakan pengalaman belajar secara nyata. Kedua, penggunaan instrumen ini membutuhkan waktu yang berkesinambungan untuk mengukur dan menilai setiap aspek kompetensi peserta didik dalam satuan waktu kurikulum pembelajaran. Untuk mendapatkan hasil yang lebih baik dibutuhkan kolaborasi team teaching, atau memberikan tanggung jawab kepada peserta didik untuk saling membantu menilai dirinya dan teman sejawatnya, agar terlaksana penilaian seluruh aspek kompetensi peserta didik. Jika rancangan pembelajaran dan instrumen penilaian benar-benar autentik dan dilaksanakan dalam proses pembelajaran akan membawa implikasi berkembangnya dimensi afektif, kognitif dan psikomotor hingga metakognisi. Sehingga dapat memberikan feedback pada pengembangan diri peserta didik baik pada kemampuan hard skills dan soft skills mereka. Ketiga, diperlukan guru yang inovatif, bertanggung jawab dan ingin mengembangkan diri. Guru harus mampu merancang aktivitas pembelajaran dan tugas yang bertujuan mengeksloprasi kemampuan peserta didik, memberikan arahan ilmiah untuk diselidiki, memiliki keterampilan dan teknik eksperimental yang relevan, karena pelaksanaan rancangan pembelajaran yang autentik harus sejalan dengan penilaian autentik dan berkesinambungan.

Hasil penelitian sesuai dengan harapan pembelajaran sosiologi kurikulum 2013. Kepiawaian guru dalam merancang, merencanakan serta melaksanakan pembelajaran berbasis authentic inquiry learning sesuai dengan kompetensi dasar dan indikator pencapaian kompetensi, serta melakukan penilaian menggunakan instrumen penilaian autentik yang valid dan reliabel, dapat mengungkapkan kompetensi peserta didik, baik dalam mencapai tujuan dalam dimensi isi (content dimension), dimensi proses (process dimension), dimensi konteks (context dimension) maupun dimensi afektif dan dimensi meta kognisi (affective dan metacognition dimension), sehingga kompetensi peserta didik baik pengetahuan, sikap maupun keterampilan dapat dinilai secara kompherensif dan berkelanjutan. Kondisi ini menjadi kelebihan dari instrumen penilaian autentik dibandingkan penilaian tradisional dimana untuk menilai sikap dilakukan dengan mengamati peserta didik saat pembelajaran, untuk menilai keterampilan peserta didik dilakukan saat diskusi kelompok, dan untuk menilai pengetahuan dilakukan pada akhir materi.

Penilaian merupakan hal yang sangat penting berkolaborasi dengan pembelajaran, sejalan dengan pendapat yang dikemukakan oleh Hyde (2013, p.196) yakni suatu penilaian diperlukan sebagai satu kesatuan utuh bersama kurikulum dan pembelajaran. Selain itu, menurut Wibowo \& Wutsqa (2014), pembelajaran di sekolah merupakan aplikasi dalam pelaksanaan kurikulum dalam mencapai tujuan pendidikan, sehingga tercapai atau tidaknya

Jurnal Socius: Journal of Sociology Research and Education Vol. 6, No.2, Th. 2019 
tujuan tersebut, maka diperlukan penilaian. Dengan demikian hasil penilaian dapat menjadi bukti sebagai pendukung hasil pencapaian masing-masing peserta didik dari waktu ke waktu.

Miller, Linn, \& Gronlund (2009, p.28) menyatakan bahwa penilaian adalah suatu proses untuk memperoleh informasi terhadap kinerja peserta didik. Penilaian autentik (Permendikbud Nomor 66, 2013, p.2) merupakan penilaian yang komprehensif secara menyeluruh. Penilaian autentik dapat digunakan sebagai tugas cerminan dari kenyataan pengetahuan yang dimiliki peserta didik (Frey, et al., 2012, p.12). Reynolds, Livingston, \& Willson(2009, pp.26-27) mengatakan bahwa penilaian autentik yang kompleks biasanya dalam bentuk penilaian kinerja. Sejalan dengan pendapat yang dikemukakan oleh Wright $(2008$, p.163) bahwa saat peserta didik melaksanakan tugas kinerja berdasarkan pada kehidupan nyata maka dapat melampui dasar minimal standar sekolah.

Hasil penilaian autentik yang diperoleh dari penelitian pengembangan instrumen ini memperlihatkan bahwa penilaian autentik berfungsi sebagai penggerak kegiatan pembelajaran dan juga untuk menilai proses dan hasil belajar peserta didik/peserta didik. Penilaian autentik dalam pembelajaran sosiologi dilakukan secara komprehensif untuk menilai masukan (input), proses, dan luaran (output) pembelajaran, yang meliputi ranah sikap, pengetahuan, dan keterampilan. Penilaian autentik juga menilai kesiapan peserta didik, serta proses dan hasil belajar secara utuh. Keterpaduan penilaian ketiga komponen (input-process - output) tersebut akan menggambarkan kapasitas, gaya, dan hasil belajar peserta didik, bahkan mampu menghasilkan dampak instruksional (instructional effect) dan dampak pengiring (nurturant effect) dari pembelajaran.

Temuan penelitian sesuai dengan teori fleksibilitas kognitif dari Spiro (1990), yang mejelaskan bahwa belajar menghasilan kemampuan secara spontan dalam restrukturisasi pengetahuan yang telah dimiliki guna merespon perubahan atau kenyataan yang dihadapi atau tuntutan seketika. Teori ini menekankan proses belajar yang tidak pernah berhenti karena harus menyesuaikan dengan situasi yang berubah-ubah atau dikatakan sebagai learning is contex dependent. Berdasarkan teori ini dapat diterima asumsi awal bahwa penilaian dalam pembelajaran harus dilakukan pada konteks belajar dan tidak terpisah dari situasi yang dihadapi. Penilaian autentik merupakan proses yang menyentuh seluruh kegiatan pembelajaran.

Selain itu teori kecerdasan multiple intelligent Howard Gardner (1983), yang mengemukakan 8 kecerdasan dasar yaitu (1) kecerdasan linguistik-verbal dan (2) kecerdasan logika matematik yang sudah dikenal sebelumnya, ditambahkan Howard Gardner dengan komponen kecerdasan lainnya yaitu (3) kecerdasan spasial-visual, (4) kecerdasan ritmikmusik, (5) kecerdasan kinestetik, (6) kecerdasan interpersonal, (7) kecerdasan intrapersonal., (8) kecerdasan naturalis. Sesuai dengan teori ini dapat diterima asumsi perlunya penilaian autentik dilakukan dengan menggunakan instrumen yang terukur, karena penilaian proses maupun belajar hasil belajar tidak hanya mengukur salah satu aspek kemampuan siswa, namun penilaian harus dilakukan secara holistik agar mampu mengukur seluruh aspek kemampuan peserta didik. Domain kognitif, afektif dan psikomotor peserta didik akan dapat berkembang lebih maksimal jika proses pembelajaran dan penilaian dirancang, dilaksanakan dan dievaluasi secara holistik dan berkesinambungan

\section{Kesimpulan}

Karakteristik instrumen penilaian autentik berbasis authentic inquiry learning, yang cocok untuk peserta didik SMA terdiri dari penilaian kinerja, penilaian sikap, penilaian presentasi, penilaian proyek, dan penilaian pengetahuan. Penilaian kinerja dan penilaian sikap 
dilakukan pada saat proses penyelidikan ilmiah dan menghasilkan produk proyek, sedangkan penilaian persentasi, penilaian produk proyek, dan penilaian pengetahuan dilakukan pada saat peserta didik melaporkan kemajuan dan laporan akhir aktivitas penyelidikan penelitian, serta mempresentasikan penelitian sebagai produk proyek. Kriteria kelayakan instrumen penilaian autentik berbasis authentic inquiry learning dinilai validitas isi dengan menggunakan formula V Aikend's diperoleh rerata sebesar 0,829 atau interpretasi tinggi. Adapun tingkat reliabilitas Alpha Cronbach sebesar 0,697 atau interpretasi tinggi, sehingga instrumen penilaian autentik yang dikembangkan layak dan daapt diimplementasikan.

Ketercapaian kompetensi sosiologi pada implementasi instrumen penilaian autentik berbasis authentic inquiry learning di kelas XI IS SMAN 1 Padang memperlihatkan kompetensi peserta didik pada penilaian pengetahuan dengan rerata 3,0 (B), penilaian sikap dengan rerata 3,5 $(\mathrm{B}+)$, dan penilaian keterampilan dengan rerata 3,1 (B). Kemampuan peserta didik menyerap materi berdasarkan pengalaman belajar mereka rerata baik, namun beberapa peserta didik masih kesulitan untuk menjawab soal HOTS dengan benar, diperlukan pemberian bahan ajar dan sumber referensi yang relevan serta pengembangan LKPD agar peserta didik mampu melatih meningkatkan kemampuan high order thinking skills mereka.

Penggunaan instrumen penilaian autentik dalam pembelajaran sosiologi yang diujicobakan pada materi masalah sosial dalam masyarakat, mengungkapkan bahwa kecapakan komunikasi (communication) peserta didik lebih baik pada indikator bertukar pikiran dan menjelaskan ide. Kecakapan kolaboratif (collaboration) peserta didik dalam mengerjakan tugas-tugas autentik dapat mendorong berkembangnya kemampuan bekerja sama dalam kelompok, berdiskusi dan mentrasformasikan ide. Instrumen penilaian autentik berbasis authentic inquiry learning ini juga dapat mengukur kecakapan peserta didik dalam berfikir kritis dan pemecahan masalah (critical thinking and problem solving), khususnya; (a) memahami masalah, (b) merencanakan pemecahan masalah, (c) menyelesaikan masalah sesuai rencana, (d) mengevaluasi hasil pemecahan masalah, dan (e) mengkomunikasikan hasil pemecahan masalah. Hasil penilaian terhadap kemampuan problem solving peserta didik, menunjukkan bahwa peserta didik memiliki kemampuan pada kategori baik. Pada kemampuan kreativitas dan inovasi (creativity and innovation), instrumen ini dapat mengukur semua indikator yang dikembangkan dan paling baik pada aspek mengkontribusikan ide-ide ke dalam dunia nyata.

\section{Daftar Pustaka}

Anderson, L. W. (2003). Classroom assessment: enhancing the quality of teacher decision making. Mahwah, NJ: Lawrence Erlbaum Associates, Publishers.

Alexakos K. (2015). Authentic Inquiry Research. In: Being a Teacher | Researcher. Bold Visions in Educational Research. SensePublishers, Rotterdam

Asri Widowati, Sabar Nurohman, Putri Anjarsari. (2016). Bahan Ajar IPA Berpendekatan Authentic Inquiry Learning untuk Meningkatkan Kemampuan Problem Solving dan Sikap Ilmiah Peserta Didik SMP. Laporan Penelitian. UNY

Ferita, R. A. (2017). Pengembangan perangkat penilaian autentik untuk pembelajaran matematika di kelas VIII semester 1. Math Didactic: Jurnal Pendidikan Matematika, 3(1), 1-9. https://doi.org/10.33654/math.v3i1.126

Frey, B. B., Schmitt, V. L. \& Allen, J. P. (2012). Defining authentic classroom assessment. Practical Assessment, Research \& Evaluation, 17(2), 1531-7714.

Gardner, Howard. 2003. Kecerdasan Majemuk. (Terjemahan Drs. Alexander Sindoro). Batam Centre: Interaksara

Jurnal Socius: Journal of Sociology Research and Education Vol. 6, No.2, Th. 2019 
Herrington, J. \& Herrington, A. (2006). Authentic conditions for authentic assessment:aligning task and assessment, in critical Vision. Proceedings of the 29th HERDSA Annual Conference, 10-12 July 2006, 146-151.

Hume, A., \& Coll, R. (2010). Authentic student inquiry: The mismatch between the intended curriculum and the student-experienced curriculum. Research in Science and Technological Education, 28(1), 43-62. https://doi.org/10.1080/02635140903513565

Hyde, D. P. (2013). What makes a good secondary assessment? On achieving the aim of assessment. Journal Education and Practice, 4(12), 188-197.

Indiana Departement of Education. (tanpa tahun). Authentic assessment. Indiana Departement of Education. Diambil tanggal 26 September 2013, dari www.msdwt.k12.in.us/msd/wpcontent/.../10/authentic_assessment.pdf.

Lombardi, M. (2007). Authentic Learning for 21st Century: An Overview. Diakses dari http://neteducause.edu/ir/library/pdf/eli3 009.pdf. pada Januari 2019

Nitko, A. J. \& Brookhart, S. M.. (2011). Educational assesment of students. Upper Saddle River, NJ: Pearson Education, Inc.

Miller M. D., Linn, R. L. \& Gronlund, N. E. (2009). Measurement and assessment in teaching. New York, NY: Pearson Education.

Kemendikbud. (2016), Permendikbud No 22 Tahun 2016 Mengenai Standar Proses Pendidikan Dasar dan Menengah, Jakarta.

Kemendikbud. (2016), Permendikbud No 23 Tahun 2016 Mengenai Standar Penilaian Pendidikan, Jakarta.

Kemendikbud. (2016), Silabus Mata Pelajaran Sekolah Menengah Atas/Madrasah Aliyah (SMA/MA) Mata Pelajaran Sosiologi Kurikulum 2013 Revisi 2016

Plomp. (2010). Educational design research: an introduction. Dalam Plomp, T. \& Nieveen, N. (Eds.), An introduction to educational design research. Proceedings of the seminar conducted at the East China Normal University, Shanghai (PR China), November 23-26, 2007. (3rd print, pp. 9-35). Netherland: Netherland Institute for Curriculum Development.

Rand J. Spiro (et.al), Cognitive Flexibility, Constructivism, and Hypertext: Random Access Instruction for Advanced Knowledge Acquisition in Ill-Structured Domains, http://phoenix.sce.fct.unl.pt/simposio, diakses pada Sepetember 2019.

Reynolds, C. R., Livingston, R. B., \& Willson, V. (2009). Measurement and assessment in education. New York, NY: Pearson.

Wibowo, R. \& Wutsqa, D. U. (2014). Evaluasi pelaksanaan kurikulum tingkat satuan pendidikan (KTSP) mata pelajaran matematika SMP di Kota Yogyakarta. Jurnal Riset Pendidikan Matematika, 1(1), 58-68

Wiggins, G. P. (1993). Assessing student performance: exlporing the purpose and limits of testing. New York, NY: Jossey-Bass Publisher.

Wright, R. J. (2008). Educational assessment: test and measurements in the age of accountability. Los Angeles, CA: Sage Publication.

Yusuf, A. Muri. (2017). Asesmen dan Evaluasi Pendidikan, Jakarta : Prenada Media Kencana Yusuf, A. Muri. (2014). Metodologi Penelitian Kuantitatif, Kualitatif \& Penelitan Gabungan, Jakarta : Prenada Media Kencana 